\title{
Idiosyncratic chloroquine retinopathy - a case report
}

\author{
H. Singh
}

\begin{abstract}
Abstrak
Klorokuin masih merupakan obat anti malaria yang terbanyak digunakan sampai saat ini. Retinopati akibat akumulasi obat telah pernah dilaporkan, terutama pada para pasien gangguan rematologik yang menjalani pengobatan jangka panjang. Sebuah laporan kasus yang langka mengenai retinopati idiosinkratik yang dicetuskan oleh klorokuin pada terapi malaria Falciparum, disajikan di sini. (Med J Indones 2002; 11: 176-8)
\end{abstract}

\begin{abstract}
Chloroquine still remains the most widely used antimalarial of present time. Cumulative dose retinopathy has been reported with the use of chloroquine therapy, especially seen in patients on its chronic therapy in rheumatological disorders. A rare case report on chloroquine induced idiosyncratic retinopathy while being used in treatment of Falciparum malaria is being presented. (Med J Indones 2002; 11: 176-8)
\end{abstract}

Keywords: cloroquine, adverse effects, idiosyncratic, malaria, retinopathy

Chloroquine retinopathy is mainly dose related. The risk of toxicity increases significantly when the additive dose exceeds $300 \mathrm{~g}$ (i.e., $250 \mathrm{mg}$ daily for 3 years) ${ }^{1,2}$ We hereby present a case of chloroquine retinopathy; where the patient developed retinopathy on a short course of therapy for malaria.

\section{CASE REPORT}

RM, 34 years old male was admitted to Pt. B.D.Sharma PGIMS, Rohtak with a 5 days history of intermittent high grade fever associated with rigor and chills and altered sensorium of one day duration. There was also history of passage of dark coloured urine for past one day. There was no history of cough with expectoration/drug treatment.

At time of admission, clinical examination revealed patient was febrile, comatosed (Coma Grade III), anaemic and jaundiced. There was mild hepatomegaly. There was no evidence of neck rigidity but planters bilaterally were extensors. Fundus revealed bilaterally

Department of Medicine, Pt. B.D. Sharma PGIMS, Rohtak, Haryana, India disc to be hyperaemic with blurring of nasal/superior margins of disc cup. Investigation revealed C.haemogram; Hb $8.2 \mathrm{~g} \%$; TLC $7500 \mathrm{~mm}^{3}$; DLC P74 L21 M3E2; erythrocyte sedimentation rate $20 \mathrm{~mm}$ in $1^{\text {st }} \mathrm{hr}$; PBF for Malaria parasites was positive for Plasmodium falciparum; urine for haemoglobin was positive by spectrophotometer; cerebrospinal fluid examination showed sugar $72 \mathrm{mg} \%$, proteins 102 mg\% and cytology revealed 1-2 Mononuclear cells/high magnification field; serum bilirubin: total $13.7 \mathrm{mg} \%$, direct $0.5 \mathrm{mg} \%$ and indirect $13.2 \mathrm{mg} \%$; SGOT/SGPT 122/142 IU; serum alkaline phosphatase $10.0 \mathrm{KAU}$ and ELISA for Australia antigen was negative; screening test (MRT) for G6PD was negative.

A diagnosis of complicated malaria (cerebral along with intravascular haemolysis leading to black water fever) due to plasmodium falciparum was made. Patient was put on parenteral chloroquine therapy along with supportive measures.

Patient responded to therapy within 24-36 hrs. He became afebrile and conscious and fundus examination was normal at $48 \mathrm{hrs}$. His biochemical profile also showed downward trend (serum bilirubin : total 9.0 $\mathrm{mg} \%$, direct $2.0 \mathrm{mg} \%$ and indirect $7.0 \%$ and SGOT/SGPT 85/114 IU). 
While he was improving clinically at $48 \mathrm{hrs}$ he started complaining of blurring and diminision of vision especially in peripheral fields. Fundus examination was repeated as it revealed normal disc. Visual acuity was found to be decreased to $6 / 24$ in both eyes. Perimetry done revealed a defect in the central field involving all the four quadrants in both eyes with a scotoma in macular area with decreased macular threshold (Figures 1 and 2). Fluorescein angiography revealed no leakage of dye in retina, so a possibility of chloroquine induced retinopathy was made and drug stopped (importantly patient had already received $25 \mathrm{mg} / \mathrm{kg}$ by then, as required for treatment of malaria).

Patient was also detailed of similar visual symptoms in the past which he denied. Since the patient was defence personnel it was assumed that the patient had no previous ocular abnormality.

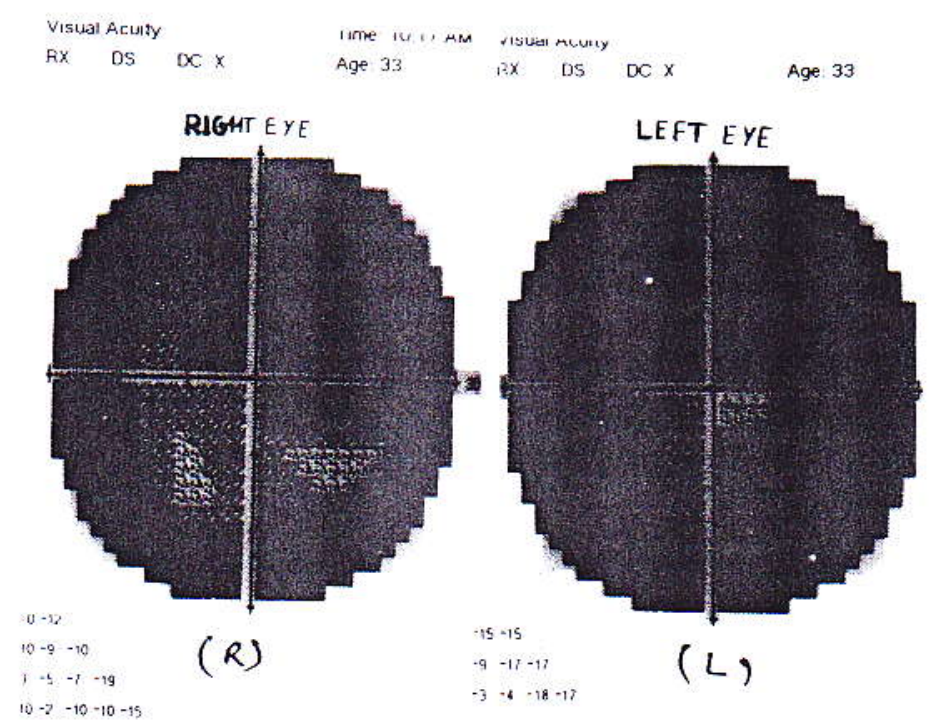

Figure 1. Central 30-2 fields of patient showing central field defects

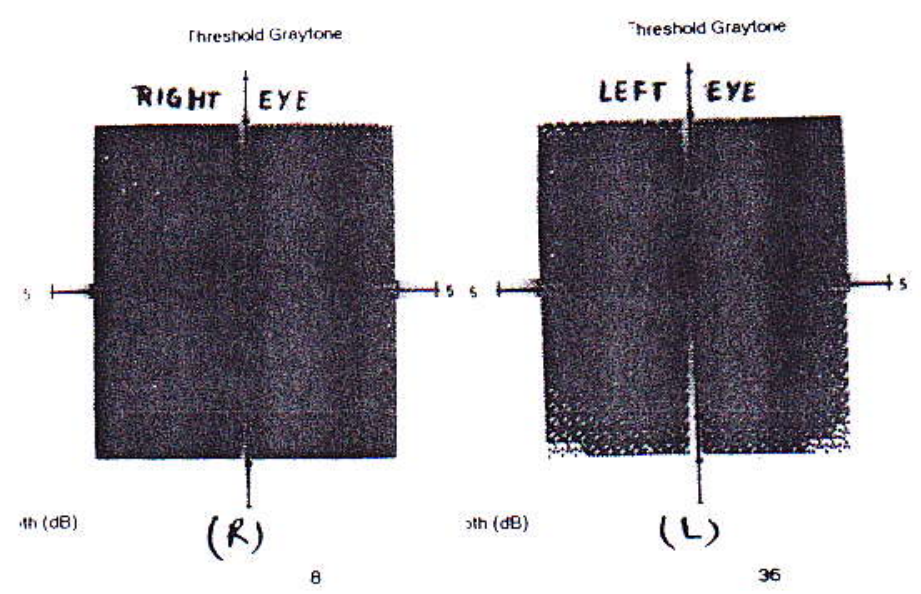

Figure 2. Macular threshold showing field defects in macular area 
Patient started improving within a week in his visual acuity (6/9) although perimetry showed field defects marginalising at 10 days of withdrawal. Patient recovered fully by one month and joined back his duty in defence services.

\section{DISCUSSION}

Chloroquine and hydroxychloroquine are commonly used in treatment and prophylaxis of malaria as well as in treatment of certain rheumatological disorders like rheumatoid arthritis, Systemic Lupus Erythematosus, juvenile chronic arthritis. ${ }^{2}$ The drug is excreted slowly from the body and especially becomes concentrated within the melanin containing structures of eye such as RPE (retinal pigment epithelium) and choroid. ${ }^{2}$ Two main side effects of chloroquine in the eye are retinopathy and corneal deposits. Amongst them the retinal changes although uncommon are potentially serious whereas comeal changes which commonly occur are innocuous. ${ }^{2}$

Chloroquine-induced retinopathy is said to be dose related and has been classified into four stages (a) Premaculopathy (b) Bull's eye maculopathy (c) Severe maculopathy and (d) End stage maculopathy. ${ }^{1,2}$ Central field damage is more severe than peripheral field damage. ${ }^{1.2}$ For screening of retinopathy, recording of visual acuity and ophthalmoscopy by prescribing doctor is desired and to any abnormality detected an opinion of ophthalmologists should be sought. ${ }^{2}$ The ophthalmologists can, if necessary perform more sophisticated tests such as visual fields, macular threshold, fluorescein angiography and electrococulography. ${ }^{2}$ A cumulative dose of less than $100 \mathrm{~g}$ or a duration of treatment under one year is rarely associated with retinal damage. ${ }^{1,2}$ Hydroxychloroquine although much expensive has been found to be much safer for risk of retinal damage when compared to chloroquine on account of passage of later but not former through blood retinal barrier.

Like any other drug, idiosyncratic chloroquine induced retinopathy remains a possibility. In our patient, chloroquine retinopathy occurred within 48 hours of therapy in which central were more affected then the peripheral field. The rate of administration of chloroquine rather than total dose could have been a factor for retinopathy as Sassani et al ${ }^{1}$ found that chloroquine when given at a rate of less than $2 \mathrm{mg} / \mathrm{lb} / \mathrm{d}$ produced no eye toxic reaction. ${ }^{1}$ Only one case of chloroquine associated retinopathy during treatment of malaria was reported to date. Highlights into adverse effects associated with anti malarial chemoprophylaxis in which transitory eye disorders were found, were reported only in therapy combining chloroquine with proguanil group and never when it was used alone. ${ }^{4}$

So our case report highlights a very rare case of idiosyncratic retinopathy with most commonly used antimalarial i.e. chloroquine.

\section{REFERENCES}

1. Sassani JW, Brucker AJ, Cobbs W and Campbell C. Progressive chloroquine retinopathy. Annals of ophthalmol $1983 ; 15: 19-22$.

2. Kanski JJ. Toxic maculopathy, In: Kanski JJ, editor. Clinical Ophthalmology - A systematic approach. $4^{\text {th }}$ ed. Oxford: Butterworth Heinemann; 1999.p.433-5.

3. Easterbook M. Detection and prevention of maculopathy associated with antimalarial agents. Int Ophthalmol Clin $1999 ; 39: 49-57$.

4. Corominas N, Gascon J, Mcjias T, Caparros F, Quinto L, Codina $\mathrm{C}$ et al. Adverse effects associated with antimalarial chemoprophylaxis. Med Clin Barc 1997; 108:772.5. 